Article

\title{
Drivers and Benefits of Integrating Climate Adaptation Measures into Urban Development: Experience from Coastal Cities of Indonesia
}

\author{
Nurrohman Wijaya ${ }^{1,2, *}$, Vilas Nitivattananon ${ }^{1}$, Rajendra Prasad Shrestha ${ }^{3}[$ and \\ Sohee Minsun $\operatorname{Kim}^{1}$ D \\ 1 Urban Environmental Management, School of Environment, Resources and Development, Asian Institute of \\ Technology, P.O. Box 4, Klong Luang, Pathumthani 12120, Thailand; vilasn@ait.ac.th (V.N.); \\ skim@ait.ac.th (S.M.K.) \\ 2 Urban and Regional Planning, School of Architecture, Planning and Policy Development, Bandung Institute \\ of Technology, Jl. Ganesha 10, Bandung, West Java 40132, Indonesia \\ 3 Natural Resource Management, School of Environment, Resources and Development, Asian Institute of \\ Technology, P.O. Box 4, Klong Luang, Pathumthani 12120, Thailand; rajendra@ait.ac.th \\ * Correspondence: st113371@ait.ac.th
}

Received: 25 November 2019; Accepted: 10 January 2020; Published: 20 January 2020

\begin{abstract}
Integrating climate adaptation measures into urban development has emerged as a holistic approach to minimize climate change impacts and to enhance urban resilience. Although there has been an initial implementation of the integrated strategy at the national level, the progress of its adoption at the local level is relatively less studied. The study aims to examine the integration development of climate adaptation measures into urban development strategies by looking at its drivers and benefits in two coastal cities of Indonesia, i.e., Semarang and Bandar Lampung. Both cities have experienced climate change impacts and the preliminary effort of the integration process. The study was depended on close-ended Likert-scale questions with key actors representing local authorities and relevant stakeholders. Then, a Weighted Average Index was applied to transform their perceptions. The assessment of their knowledge of related issues was conducted. Secondary data was obtained from a desk study. The study found out that the effort of the integration process had influenced stakeholder's understanding of the issue of climate change and urban development, as well as its relationship. The level of stakeholder's knowledge related to the issue was very high. The result also revealed that the most influencing driver of the integration process is related to the motivation and initiative of municipal officers. It significantly contributed local governments to adopt its integration strategy. There was a strong consensus regarding the benefits of the integration process. They believed that it could ensure sustainable urban development in the future. This empirical study distinguishes the significance of integration development based on the local perspective for the approach improvement. The results could be applied to encourage other local municipalities in other emerging coastal cities.
\end{abstract}

Keywords: climate adaptation; coastal city; drivers and benefits; integration progress; local perspective

\section{Introduction}

Climate change (CC) has been widely known as a global issue that affects the local level due to its adverse impacts on urban development [1,2]. In the meantime, ongoing rapid urbanization and a growing urban population have also occurred, particularly in developing Asian countries [3]. Currently, 53 percent of the world's urban population lives in Asia. In 2020, it is predicted that more than half 
the population will reside in urban areas [4], including coastal cities in Indonesia. Coastal cities turn into vulnerable regions because of the concentration of people, infrastructure, and socio-economic activities [5]. Indonesia, an archipelagic country with long coastal lines, is one of the most vulnerable countries to CC impacts, such as sea-level rise, coastal flooding, and extreme weather events, that have faced many social, economic and environmental stressors [6,7]. The national government has attempted to minimize the impacts by planning CC adaptation measures, such as the National Action Plan for Climate Change Adaptation [8]. Although it is not mandatory, local governments and other relevant stakeholders have initiated to implement adaptation activities with the primary support of international development agencies and non-government organizations (NGOs).

The adoption of climate adaptation actions has been followed by the efforts to integrate the measures into local development planning [9-12]. An integrated approach has emerged as a holistic idea to minimize CC impacts and to enhance urban resilience at the local level. Many international donors and multilateral projects in Indonesia have been influencing and supporting the integration process (i.e., the Rockefeller Foundation, the German Development Agency of GIZ, the World Bank, and the Japan International Cooperation Agency). They consider the involvement of local government and community groups as units of planning and implementation in the process $[12,13]$. This engagement has been done with the assumption that those local stakeholders have the potential to address both CC and developmental concerns collectively, and able to provide a firm local institutional base to implement these plans. It is expected that the outcome generated by the integration process has influenced the understanding of local actors related to the issues. Their knowledge can play a significant role in assessing CC and its adaptation strategies that have been increasingly recognized.

Many recent works of literature explain the association between CC adaptation and urban development [1,14-16]. However, research on the adoption of integrated approach progress at the local level is still limited. Most of CC adaptation mainstreaming studies and practices have been focused on development policy at the national level [9,17-19]. Also, it is essential to clearly understand the local knowledge of stakeholders [20] as a result of the approach implementation. To enhance the integration process, local decision-makers and related stakeholders need a clear understanding of potential CC impacts and the urban development planning process. Previous studies emphasized the use of local knowledge together with scientific knowledge. The merging of both insights enables us to gain a better understanding of CC and its impacts as well as to perceive the progress of effective local strategies to minimize vulnerability [21,22]. Local knowledge and its perception can supplement and support recent CC research that is still common with uncertainties. Adger et al. [23] and Harvatt et al. [24] emphasized that individual knowledge and experiences influence perception of future adaptation practices, which in turn influence responses and management of the integration strategy. By understanding the local perspective, it is expected that it can contribute to developing effective interventions to improve the integrated approach.

The objective of this study is to assess the integration progress of climate adaptation measures into urban development strategies by looking at its drivers and benefits in the two selected coastal cities of Indonesia: Semarang and Bandar Lampung. In the beginning, this study also examines local stakeholders' knowledge related to the issue of CC and urban development. Both cities have imposed by the impacts of CC and been experiencing the initial adoption of the integrated approach. Lessons learned from this study will enable the sharing of these findings and experiences with other urbanized coastal areas.

The structure of the remaining parts of this paper is as follows. First, we overview the conceptualization of climate adaptation at the local level, urban coastal development, and the drivers and benefits of the integrated approach. The next sections briefly review the study areas and the methodology. The level of respondents' knowledge, the main findings of the key drivers affecting the integration process, and its benefits are then presented. The last section describes the lesson learned and the conclusion of the study. 


\section{Literature Review}

\subsection{Climate Adaptation at the Local Level}

Adaptation concerns are not only to its climatic stimuli but also to non-climate circumstances, sometimes called intervening conditions, which serve to influence the sensitivity of systems and the nature of their adjustments [5,25]. The Intergovernmental Panel on Climate Change (IPCC) report defined adaptation as "the adjustment in natural or human systems in response to actual or expected climatic stimuli or their effects, which moderates harm or exploit beneficial opportunities" [26]. IPCC $[5,26]$ stated that adaptation in the CC issue is a significant consideration because of their severe impacts and higher vulnerabilities, especially for communities and affected areas with low adaptive capacities, as well as its influence to the development and evaluation of response options. The attention regarding CC adaptation is more likely focused mainly at the local level due to the impacts of CC that have been recognized significantly in local and context-specific $[11,27,28]$. Three main reasons can be identified that local climate adaptation is essential: First, CC impacts are manifested locally corresponding to local natural features and other environmental, political, and socio-economic factors $[11,28]$. Second, climate risks are also realized locally, resulting from the combinations between socio-ecological elements and their practices. Lastly, most adaptation decision making and action can be perceived at local levels according to their experience, knowledge, and capacity of CC impacts. Feldmeyer et al. [29] pointed out that climate adaptation at the local level (specifically at the city level) can be measured as part of urban resilience by looking at five dimensions, including environment, infrastructure, governance, economy, and society.

Bulkeley [15] and Laukkonen et al. [30] mentioned that the stage of adaptation planning and implementation is often appropriate at local governance systems which are the 'closest' elements for the particular environmental and socio-economic context. Pasquini et al. [31] also argued that local governments represent the first opportunity for applying adaptation measures to the CC impacts. Besides, cooperation, coordination and public participation among related stakeholders in the process of local climate adaptation planning is required [32] as well as incorporating socio-economic pressures in vulnerability assessment is essential [33].

\subsection{Urban Coastal Development}

Urban areas were have become a hotspot for both the causes and consequences of CC are increasingly visible in recent adaptation research $[13,34]$. Urban development is becoming an expected result of the growing cities. Its pressures have given a significant influence including an increasingly urban population, pollution, slum, and squatter areas. On another hand, the phenomenon of CC also affects urban areas, for example, is contributing to increasing infrastructure damage, vector-borne disease, and natural resource degradation. OECD [35] stated that CC adaptation becomes a critical development issue. Coastal urban areas have continually been exposed to natural hazards and become the hotspots of vulnerability due to CC. Many of the largest cities are located in coastal regions [4] and are thus exposed to projected increases in sea level, storm activity, and associated flooding [34]. The most significant threat that coastal settlements are facing is the sea-level rise and thus coastal flooding. Many coastal cities have degraded natural floodplain storages such as grasslands, wetlands, salt marshes, and mangroves in favor of housing or commercial property.

Moreover, as a range of coastal urban areas offers port facilities, their coasts are lacking natural defense lines. Increased salinity in estuaries and coastal aquifers, as well as coastal erosion, have also contributed to degraded coastal zones around urban areas along the shoreline [3,5,36]. Thus, it is essential to consider the progress of local climate adaptation measures related to urban development sectors, especially in coastal cities, before beginning the integration strategy as a holistic approach. 


\subsection{Drivers and Benefits of the Integration Strategy}

The Fifth Assessment Report has mentioned the need to integrate CC adaptation into urban development planning [5] to minimize the CC impacts. Fuchs et al. [10] stated that efforts to address the CC impacts in developing countries have for some time called for mainstreaming adaptation in development planning, that is the integration of adaptation in development planning across sectors and agencies as opposed to as a stand-alone process. Persson and Klein [37] argued that adaptation is the result of many actions that influence policy decision making based on several different aspects so that it is necessary to consider the mainstreaming process comprehensively. Sherman [38] mentioned the importance of the linkage between adaptation and development. However, it requires further strengthen adaptive urban governance and strategic planning [39]. In this study, we define integration as a holistic approach that not only concerns mainstreaming climate adaptation measures into urban development policies but also its process including the capability of local government and other aspects.

In the context of the local level, the integration of climate adaptation into municipal development planning becomes significant [40-42]. In the last decade, the initial efforts have been recognized notably in developing countries [11,28,31]. Some of the adaptation practices have been discovered in Indonesia's municipalities, such as building adaptive capacity (e.g., research, awareness-raising, training, and advocacy), creating a suitable institutional environment (e.g., city team workforce), and implementing adaptation (e.g., mangrove plantation) [43]. From the previous studies [9,38,44-46], some influencing drivers for integration process can be found, including the officers' motivation, initiative, and leadership, the assistance, and support by government and international development agencies, the existence of policy direction and guideline as well as the political will of decision-makers.

Several benefits of the integration strategy as a holistic approach can be identified. Persson and Klein [37] stated that the action plan to integrate CC adaptation into current government plans and programs could ensure the sustainability and impact of local involvement. Nowadays, many advocates among international development agencies in developing countries are distinguishing the benefits of integration or mainstreaming climate adaptation measures into development planning $[5,9,12,47,48]$, such as increasing the institutional capacity (such as collaboration and partnership), reducing maladaptation measures, increasing cost-effectiveness, raising public engagement, making mutual recognition among stakeholders, and improving the co-benefit between development and adaptation. Ayers et al. [9] explained that the integration of measures and policies to mention CC into current development planning and public decision-making should make "no regrets" prospects for reaching resilient development and avoid possible tradeoffs between adaptation and development plans that could make mal-adaptation in the upcoming years.

Based on the previous description, this study uses the assumption that the involvement of local stakeholders in the integration process will increase their understanding related to the issues of CC and urban development (e.g., its perception of advantages gained from the process). It is expected that their recognition can play a significant role to provide a firm local institutional base as well as to improve the effective interventions of the approach.

\section{Study Areas Profiles and Related Adaptation Measures}

The two case study areas were selected representing large and medium-sized coastal cities of Indonesia: Semarang and Bandar Lampung, respectively. They are situated on the north coast of Java Island, and the south coast of Sumatera Island, respectively (Figure 1). Both cities had experiences regarding the evidence of $\mathrm{CC}$ impacts, and the initial efforts of climate adaptation practices. They were part of the Asian Cities Climate Change Resilience Network (ACCCRN) program under the Rockefeller Foundation for the preliminary adoption of the integration process. One of the adaptation practices in the cities included the establishment of a city working group, consisting of local government officials, local NGOs, and academics. The working group of both cities had initiated the integration of CC adaptations into their urban development planning and policy with support from international development agencies $[49,50]$. 


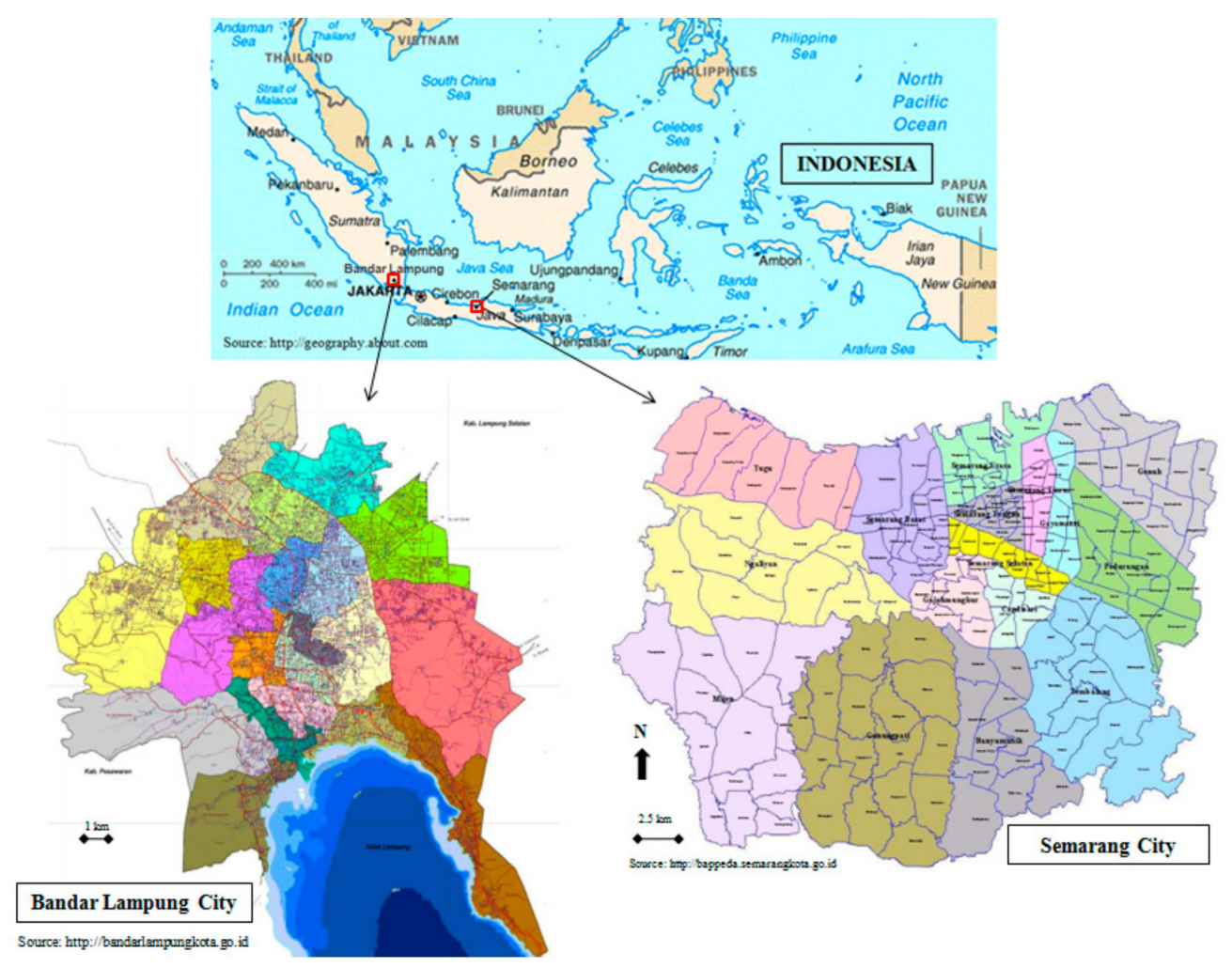

Figure 1. Location of two coastal cities studied: Bandar Lampung and Semarang. Source: modified from http://bandarlampungkota.go.id, and http://bappeda.semarangkota.go.id.

Both cities have experienced significant urban growth in recent years. Semarang is the capital and the largest city of Central Java Province. The area is 373.78 square kilometers, and the population is about 1.8 million people. It is Indonesia's fifth-most populous city, following Jakarta, Surabaya, Bandung, and Medan. Based on the 2010 census, the metropolitan area has 3,183,516 people spread between two cities and 26 districts [51]. Concerns about climate and development are evident in its long-term development and spatial plans. In Semarang's comprehensive plan, the primary goal of Semarang for 2050 is to preserve cultural and physical resources and to make all neighborhoods more liveable [49].

Meanwhile, Bandar Lampung is the capital and a major economic hub in Lampung Province in the southern part of Sumatra Island, Indonesia. The city's area is about 118.5 square kilometers, with a population of 879,651 people at the 2010 Census. The latest estimate (January 2014) is 923,970 people [52]. Based on the vulnerability assessment, Bandar Lampung recognized it is facing several climate change impacts including flood, erosion and landslide, drought, coastal erosion, and sea-level rise [50].

Although there is dynamic economic development (such as large-scale infrastructure, industrial estate, and the leading sectors developments), the two cities are still facing the challenges of urban development such as high levels of poverty, education, pollution, and housing. Nevertheless, changes in mean and extreme temperatures and rainfalls, as well as other natural hazards, such as floods and droughts, will be more exaggerated with CC. Generally, CC is still given less attention in these cities when compared with other development priorities. The top-down approach and business-as-usual practices are still more dominant in administration and planning, resulting from the capacities of policy decision-makers and related stakeholders in both cities to formulate and execute CC adaptations. The priority issues surrounding vulnerability tended to be defined sectorally, such as flood protection, water supply, solid waste management, and public health [53]. Revi et al. [54] argued that rapid growth in cities of the developing countries has not always been followed by suitable planning processes and adequate risk-reducing around necessary infrastructure and services. Consequently, many local people 
in urban areas are not prepared for the CC impacts that it is estimated to bring and thus will deal with major urban development challenges.

However, they are excellent case areas where local authorities attempt to pay attention at the initial stage to integrate CC adaptation measures into urban development sectors, including incorporating the measures to urban development plans and strategies [43]. Efforts can be seen in public documents of spatial and development plans. Selected climate adaptation measures related to major urban development problems of the two cities can be seen in Table 1. Several climate adaptation activities and cooperation with international agencies have also been discovered in both cities [49,50]. In terms of the institutional arrangement, the leadership of the indicator development role varied from the two cities. In Semarang, the key players of the climate adaptation activities are the University of Diponegoro (UNDIP) and Local Development Planning Agency (BAPPEDA), while in Bandar Lampung, Local Environmental Management Agency (BPLHD) and BAPPEDA are the main actors for the adaptation process.

Table 1. Selected integrated strategy between climate adaptation measures and major urban development sectors of two selected coastal cities in Indonesia.

\begin{tabular}{|c|c|c|c|}
\hline City & Related Urban Issue & Adaptation Action & Strategy \\
\hline \multirow{4}{*}{ Bandar Lampung } & $\begin{array}{l}\text { Waste management } \\
\text { Human development } \\
\text { (health) }\end{array}$ & $\begin{array}{l}\text { The master plan for } \\
\text { integrated solid waste } \\
\text { management }\end{array}$ & $\begin{array}{c}\text { Improving resilience against climate change by } \\
\text { combining the projection of health-related } \\
\text { climate change and resilience with solid waste } \\
\text { management }\end{array}$ \\
\hline & Water security & $\begin{array}{l}\text { Groundwater } \\
\text { conservation using } \\
\text { biopori }^{1}\end{array}$ & $\begin{array}{l}\text { Biopori infiltration holes can help the soil to } \\
\text { absorb and accommodate water quicker }\end{array}$ \\
\hline & $\begin{array}{l}\text { Human development } \\
\text { (education) }\end{array}$ & $\begin{array}{l}\text { Empowerment and } \\
\text { capacity building of } \\
\text { teachers and students to } \\
\text { improve city resilience } \\
\text { against climate change }\end{array}$ & $\begin{array}{c}\text { Climate change educational action produced } \\
\text { supplementary teaching materials on climate } \\
\text { change for primary school and junior high } \\
\text { school levels }\end{array}$ \\
\hline & Waste management & Trash to cash & $\begin{array}{l}\text { Creating a financial, operational, and social } \\
\text { evolution that could guarantee sustainable } \\
\text { management of waste banks }\end{array}$ \\
\hline \multirow{4}{*}{ Semarang } & $\begin{array}{l}\text { Urban disaster reduction } \\
\text { (urban planning) }\end{array}$ & $\begin{array}{l}\text { Flood early warning } \\
\text { system }\end{array}$ & $\begin{array}{l}\text { Building resilience towards particular } \\
\text { watershed through the combination of } \\
\text { technology and community participation }\end{array}$ \\
\hline & Water security & Rainwater harvesting & $\begin{array}{l}\text { Introducing rainwater harvesting as an } \\
\text { additional water supply }\end{array}$ \\
\hline & $\begin{array}{l}\text { Human development } \\
\text { (health) }\end{array}$ & $\begin{array}{l}\text { Actions changing the } \\
\text { incidence of vector-borne } \\
\text { endemic disease }\end{array}$ & $\begin{array}{l}\text { Increasing urban resilience by reducing the risk } \\
\text { of dengue }\end{array}$ \\
\hline & $\begin{array}{l}\text { Urban planning } \\
\text { Human development } \\
\text { (education) }\end{array}$ & $\begin{array}{c}\text { Enhancing coastal } \\
\text { community resilience by } \\
\text { strengthening mangrove } \\
\text { ecosystem service and } \\
\text { developing sustainable } \\
\text { livelihoods }\end{array}$ & $\begin{array}{l}\text { Delivering more knowledge related to climate } \\
\text { change impacts, mangrove plantation, } \\
\text { breakwaters and fish that is more adaptive to } \\
\text { salinity changes to the communities }\end{array}$ \\
\hline
\end{tabular}

Several adaptation actions related to urban development sectors have been implemented in the two selected cities including health, water, human development, and urban planning. Most of the strategies in Table 1 are city-wide initiatives. Although, urban development sectors of water security, health and education are the most common activities to promote water conservation, urban health resilience, and knowledge sharing, both cities have different adaptation actions regarding their specific $\mathrm{CC}$ risks. Besides the areas of water security and education, Bandar Lampung emphasizes more on waste management, while, Semarang concerns more on health. 


\section{Methodology}

In the earlier sections, it was shown that the selected coastal cities have some adaptation initiatives which contribute to the realization of the integration process between adaptation measures and urban development sectors. It was necessary to investigate the progress of the integration process based on stakeholders' perceptions regarding the issues. In this context, local knowledge of stakeholders was examined. In addition, the drivers contributing to the integration strategy and its benefits were also studied (see Figure 2).

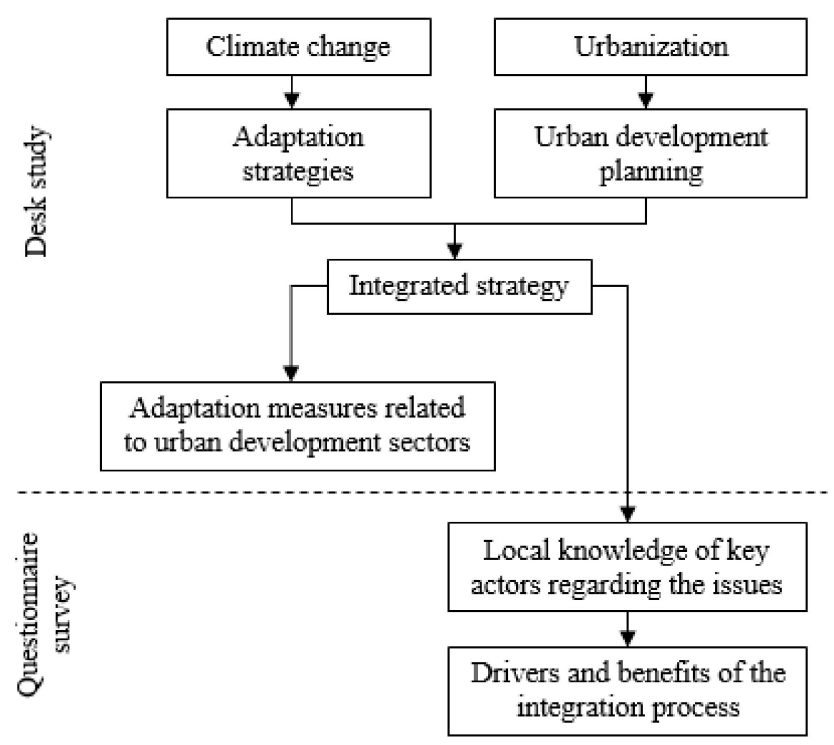

Figure 2. The analytical framework.

\subsection{Data Collection}

The study relied on fieldwork and a questionnaire survey with key actors from the two coastal cities that were undertaken between September 2015 and January 2016. Key informants in each of the designated cities were selected based on their representative individual or organizational responsibility in the urban environmental management issues of the cities. They were also limited to those directly involved in climate adaptation practices in their respective cities. They included local and provincial government officials (e.g., BAPPEDA, BPLHD, Local Disaster Mitigation and Preparedness Agency (BPBD)), NGOs (e.g., Mercy Corps), community-based organizations (CBOs) (e.g., Bina Karta Lestari (BINTARI)), academic and research institutions (e.g., University of Bandar Lampung (UNILA), Institute of Technology Sumatera (ITERA), UNDIP). A total of 43 respondents were selected from two coastal cities. There were 22 from Semarang, and 21 from Bandar Lampung. This study did not attempt to assess the similarities or differences of the perception among the respondents. They answered the same set of questions. The questionnaire emphasized the respective cities and their actions towards attaining an integrated process between climate adaptation measures and urban development plans.

In order to effectively achieve the objectives, the close-ended Likert-scale questions were conducted into three main groups, which are 1) general knowledge on CC and urban development, 2) drivers affecting the integration process, and 3) benefits of the adoption of integration strategy. The variables in each group were acquired from a literature review and a preliminary survey. Responses were on a scale of 1-5 dealing with the main questions as follows: 1) "How much do you agree with the statements specifically on the knowledge of CC and urban development?" (1, strongly disagree, 5, strongly agree), 2) "How much do you agree with the statements specifically on drivers influencing the integration process?" (1, strongly disagree, 5 , strongly agree), and 3) "How much do you agree with the statements on the benefits of the integration process?" (1, strongly disagree, 5 , strongly agree). 
Due to time and distance constraints, the study had a limited number of respondents that may affect the results. It was also relatively challenging to attain the respondents who have involved in a specific issue on urban development and CC adaptation. However, from the result of the survey, the intention to get more respondents in the government level was achieved. Of the key respondents, $72 \%$ were local government officers, such as BAPPEDA, BPLHD, BPBD, Local Agency for Meteorology, Climatology, and Geophysics (BMKG), the Local Agency for Public Health, and the Local Agency for Public Work. Also, 18.2\% of the targeted respondents were working at the NGO/CBO, which are the Indonesian Association for Sustainable Development (BINTARI), and the Mercy Corps based on respective cities. The remains were those from academic or research institutions (9.1\%) including the experts from (ITERA and UNILA in Bandar Lampung, and UNDIP in Semarang. Secondary data was also obtained from a desk study of the two cities, including various journal papers, reports, regulations, and plans (e.g., the strategic and development plans).

\subsection{Data Analysis}

The study applied content analysis to analyze secondary data, such as public and non-governmental reports and plans (e.g., the development plans). A quantitative method was used to investigate local knowledge and perception of key informants related to CC adaptation and urban development issues, as well as the influencing drivers and its benefits from the adoption of the integrated strategy. A scale was applied to convert the respondents' responses for statistical analysis. A Weighted Average Index (WAI) was applied to convert the responses of respondents from an ordinal scale (strongly agree-strongly disagree) into numeric scores. The scores were categorized into five levels: $0.00-0.20=$ strongly disagree, $0.21-0.40=$ disagree, $0.41-0.60=$ moderate, $0.61-0.80=$ agree, $0.81-1.00=$ strongly agree. Since the data did not follow the normal distribution or the homogeneity of the variances, a non-parametric statistical analysis of Wilcoxon-Mann-Whitney was applied to identify the significant difference between the two test groups. Nanna and Sawilowsky [55] suggested that non-parametric tests are more suitable for analyses involving ordinal scales. Significant differences were considered at $p$-value $<0.05$. The WAI values in the same row superscripted with ' $a$ ' is significantly different from those superscripted with 'b.' Values with the same superscript, ' $a$ ' or ' $b$ ' are not significantly different. Higher WAI values mean a stronger response to the questions.

\section{Results and Discussions}

\subsection{Local Knowledge of CC and Urban Development Issues}

It is necessary to recognize the local knowledge of key informants regarding their understanding of the issues of CC and urban development, particularly as the outcome of the adoption of the integration process. To achieve this objective, we allowed the respondents to answer six statements related to the issues. The statements were developed based on reviewing some literature. Their responses are presented in Table 2. It was found that the respondents' knowledge level has a high score as indicated by WAI values of 0.867 to 0.939 . It means that their local knowledge has given a high influence, especially on responding to the questions of drivers and benefits of the adoption of integration strategy in the next section. 
Table 2. Respondents' perception of CC and urban development issues.

\begin{tabular}{|c|c|c|c|}
\hline \multirow[b]{2}{*}{ Statements } & \multicolumn{3}{|c|}{ WAI } \\
\hline & $\begin{array}{l}\text { Semarang } \\
\left(n_{1}=22\right)\end{array}$ & $\begin{array}{l}\text { Bandar Lampung } \\
\qquad\left(n_{2}=21\right)\end{array}$ & $\begin{array}{c}\text { Total } \\
(N=43)\end{array}$ \\
\hline $\begin{array}{l}\text { CC is one of the most serious } \\
\text { socio-economic and environmental } \\
\text { challenges in urban coastal areas }\end{array}$ & $0.965^{\mathrm{a}}$ & $0.913^{\mathrm{a}}$ & 0.939 \\
\hline $\begin{array}{l}\mathrm{CC} \text { is marked by extreme weather } \\
\text { events, sea-level rise, severe drought, } \\
\text { and flooding. }\end{array}$ & $0.965^{a}$ & $0.875^{b}$ & 0.921 \\
\hline $\begin{array}{l}\text { Besides mitigation, adaptation } \\
\text { measures are needed to minimize the } \\
\text { impacts of } C C\end{array}$ & $0.965^{\mathrm{a}}$ & $0.850^{b}$ & 0.909 \\
\hline $\begin{array}{l}\text { There is a significant relationship } \\
\text { between } C C \text { and urban development }\end{array}$ & $0.941^{\mathrm{a}}$ & $0.813^{b}$ & 0.879 \\
\hline $\begin{array}{c}\text { CC can contribute to the complexity of } \\
\text { urban coastal management }\end{array}$ & $0.929^{a}$ & $0.800^{b}$ & 0.867 \\
\hline $\begin{array}{l}\text { Urban coastal areas become the hotspots } \\
\text { of vulnerability due to CC impacts }\end{array}$ & $0.894^{\mathrm{a}}$ & $0.838^{a}$ & 0.867 \\
\hline
\end{tabular}

Source: authors' analysis from the questionnaire survey. Note: values with the same superscript, ' $a$ ' or ' $b$ ', are not significantly different, and vice versa.

Overall, the respondents strongly agreed (0.939) that CC is one of the most severe environmental and socio-economic problems that affect urban development. Moreover, the two cities have the same significant degree for the agreement as shown in Table 2. This finding indicated that they already recognize the impacts of $\mathrm{CC}$ to the development of urban coastal areas according to their experiences, i.e., not only the loss of the settlement and wetland areas but also the decrease of municipal finance and health due to sea-level rise. This result was also affirmed by the statement that there is a significant linkage between CC and urban development. Most respondents strongly agreed (0.879). However, Semarang and Bandar Lampung had significant statistical different degrees. It indicated that both cities have a different status of CC impacts and urbanization growth, including the development of infrastructure and basic facilities.

They also confirmed (0.921) that among the other causes, CC is marked by extreme weather events, sea-level rise, severe drought, and flooding. However, this statement did not influence the two cities to the same degree. It was observed that the two coastal cities have different CC impacts depended on certain aspects such as geographic and topographic conditions as well as the degree of CC impacts. For example, in the case of Semarang, frequent coastal flooding and sea-level rise are happened, while in Bandar Lampung, flooding and erosion are always occurred due to the tidal wave.

The majority of respondents strongly agreed (0.909) that besides mitigation, adaptation actions are needed to minimize the CC impacts. The findings indicated that it was the third most crucial statement in the two coastal cities as shown in Table 2. However, there was a statistical significance difference, because both cities have different adaptation measures (see Table 1) which are, among the others, dependent on the physical characteristics of the city, the institutional capacity, and the budget. For example, the local government of Semarang planned to mitigate the impacts by constructing the sea wall and waterway [56]. Regarding the complexity of urban management due to CC contribution, most respondents strongly agreed (0.867) that it can influence local governments to resolve the urban problems with a more strategic and integrated approach by looking at all aspects. Between WAI values, there were significant differences. For example, informal settlement along the coastal line in Bandar Lampung is one of the urban issues that need to be solved. However, the impact of CC has exacerbated the situation. Meanwhile, in Semarang, industrialization along the coastal area is one of the urban 
challenges, which exploits groundwater and makes pollution. However, the rising of sea level makes the situation worse than without CC impacts.

Most respondents in the two cities understood that, presently, their urban coastal area is becoming a hotspot of vulnerability due to CC impacts. Although there was no statistically significant difference as indicated in WAI values, it was observed that Semarang is more agreeable (0.894) to the statement than Bandar Lampung (0.838). It is revealed by the higher number of adaptation actions and the complexity of urban issues in the larger city.

Comparison of WAI values in the two coastal cities showed the difference ranked agreement among all statements related to CC and urban development issues. Although the values of Bandar Lampung are slightly lower than Semarang, the statements on CC as one of the critical challenges, the symptoms of CC, and the importance of CC adaptation and mitigation indicate similar highest-ranked agreement and understanding between the two respective cities. The implication of this finding based on respondents' knowledge regarding CC and the urban environment show a significant willingness to apply the adaptations (total score is more than 0.850), particularly how their influence and decision on the process of integration strategy. The previous studies $[57,58]$ explained that perceived knowledge has influenced the people to make a decision to adapt. It has essential consequences both on assessment of vulnerability and adaptation, and on intervention to promote adaptation measures.

\subsection{Drivers Influencing the Implementation of Integration Strategy}

It was important to understand the drivers contributing to the implementation of the integration strategy based on stakeholders' experiences. The respondents' responses are shown in Table 3. It was found that out of nine drivers, one has moderate (0.564) and eight have strong (0.642 to 0.794) influence on the adoption of the integration strategy. Motivation and initiative of local officers (0.794), the central government support (0.764), and capacity building actions (0.758) are the first, second, and third most important influencing drivers for contributing the process of integration strategy in Semarang and Bandar Lampung. It influences the cities with the same degree, shown in Table 3. These findings reveal that government support and capacity building have motivated the municipal officers to implement the adaptation measures associated with urban development issues actively. The Government of Indonesia was assisted by several international agencies in order to adopt CC adaptation measures into urban development plans. Although the effort is still in the early stage, it could be an opportunity to enhance the urban climate-adaptive development program, especially at the local level.

The assistance provided by international development agencies (0.745) in both cities is the fourth most essential influencing driver. However, it did not influence the cities to the same degree as shown in Table 3. It was observed that Semarang has more intention to adopt the strategy due to support by international development agencies and national government, i.e., the program of 100 Resilience Cities. The government of Indonesia considers Semarang as the pilot city for implementing the program because of the readiness and suitability program with the local development plan. The result is confirmed by the paired comparison of WAI values between Semarang and Bandar Lampung. The support of international development agencies is the highest influencing driver in Semarang as indicated by the WAI value of 0.882. Meanwhile, in Bandar Lampung, it is at a moderate level (0.600). 
Table 3. Respondents' perception of drivers that contribute to the integration strategy.

\begin{tabular}{|c|c|c|c|}
\hline \multirow[b]{2}{*}{ Drivers } & \multicolumn{3}{|c|}{ WAI } \\
\hline & $\begin{array}{l}\text { Semarang } \\
\left(n_{1}=22\right)\end{array}$ & $\begin{array}{l}\text { Bandar Lampung } \\
\qquad\left(n_{2}=21\right)\end{array}$ & $\begin{array}{c}\text { Total } \\
(N=43)\end{array}$ \\
\hline $\begin{array}{l}\text { Motivation and initiative of } \\
\text { municipal officials }\end{array}$ & $0.800^{a}$ & $0.788^{a}$ & 0.794 \\
\hline $\begin{array}{l}\text { Support received by the central } \\
\text { government }\end{array}$ & $0.824^{a}$ & $0.700^{\mathrm{a}}$ & 0.764 \\
\hline $\begin{array}{l}\text { Capacity building to transform } \\
\text { knowledge into action (workshop, site } \\
\text { visit, role models) }\end{array}$ & $0.824^{\mathrm{a}}$ & $0.688^{a}$ & 0.758 \\
\hline $\begin{array}{c}\text { Assistance provided by } \\
\text { partners/international development } \\
\text { agencies }\end{array}$ & $0.882^{\mathrm{a}}$ & $0.600^{b}$ & 0.745 \\
\hline $\begin{array}{l}\text { The existence of guidelines issued by } \\
\text { government agencies }\end{array}$ & $0.753^{a}$ & $0.713^{a}$ & 0.733 \\
\hline $\begin{array}{l}\text { Strong collaboration and coordination } \\
\text { across local municipal sectors }\end{array}$ & $0.635^{a}$ & $0.675^{a}$ & 0.655 \\
\hline $\begin{array}{l}\text { Policy directives and normative trends } \\
\text { toward integration strategy }\end{array}$ & $0.612^{a}$ & $0.675^{a}$ & 0.642 \\
\hline $\begin{array}{l}\text { Active participation of people and } \\
\text { related stakeholders }\end{array}$ & $0.600^{\mathrm{a}}$ & $0.688^{a}$ & 0.642 \\
\hline $\begin{array}{l}\text { Political will and commitment of } \\
\text { decision-makers }\end{array}$ & $0.494^{\mathrm{a}}$ & $0.638^{a}$ & 0.564 \\
\hline
\end{tabular}

Source: authors' analysis from the questionnaire survey. Note: values with the same superscript, ' $a$ ' or ' $b$ ', are not significantly different, and vice versa

Excluding the driver of the partners' assistance, there were no significant differences among respective WAI values. The existence of guidelines (0.733) was slightly more influential than strong collaboration and coordination among local municipal sectors (0.655), policy and normative directions toward integration strategy (0.642), public participation (0.642), and political will and decision-makers' commitment (0.564). These findings confirm the previous study [45] that individuals' engagement will contribute to implementing the climate adaptation agenda at the local level. In this case, giving assistance and support as well as capacity building to, mainly, the local officers are able to enhance the motivation and initiative them to adopt the integration strategy.

\subsection{Benefits of Climate Adaptive Development Integration Strategy}

Also, the results related to the significance of integration can be seen in Table 4. Overall, most respondents believed that integrating climate adaptation into urban development can ensure sustainable development in the long term (0.939), and to minimize CC impacts and risk (0.927).. In Semarang, the highest significance score of the integration was reached by the statement of enhancing the collaboration and partnership among stakeholders (0.988). While in Bandar Lampung, the significance of the integration is to ensure sustainable development in the long term (0.900). Ensuring sustainable urban development in the future is the highest-ranked benefit (0.939) for adopting an initial integrative approach. However, these benefits did not influence the two cities to the same degree as shown in Table 4. It was observed that Semarang as one of the large cities in Indonesia that has much complexity of urban development issues, Meanwhile, Bandar Lampung as a medium-city did not receive any such support or assistance from government and international development agencies. These findings reveal that a common benefit of adaptation is to minimize the impacts and risks. 
Table 4. Respondents' perception of the benefits of integration strategy adoption.

\begin{tabular}{|c|c|c|c|}
\hline \multirow[b]{2}{*}{ Benefits } & \multicolumn{3}{|c|}{ WAI } \\
\hline & $\begin{array}{l}\text { Semarang } \\
\left(n_{1}=22\right)\end{array}$ & $\begin{array}{l}\text { Bandar Lampung } \\
\qquad\left(n_{2}=21\right)\end{array}$ & $\begin{array}{c}\text { Total } \\
(N=43)\end{array}$ \\
\hline $\begin{array}{c}\text { Ensuring sustainable urban development in } \\
\text { the long-term period }\end{array}$ & $0.976^{\mathrm{a}}$ & $0.900^{\mathrm{b}}$ & 0.939 \\
\hline Minimizing CC impacts and risks & $0.976^{\mathrm{a}}$ & $0.875^{b}$ & 0.927 \\
\hline Raising public participation & $0.965^{\mathrm{a}}$ & $0.838^{\mathrm{b}}$ & 0.903 \\
\hline $\begin{array}{l}\text { Enhancing collaboration and partnership } \\
\text { among related institutions }\end{array}$ & $0.988^{a}$ & $0.800^{b}$ & 0.897 \\
\hline $\begin{array}{l}\text { Improving the rationality and effectiveness } \\
\text { of policy }\end{array}$ & $0.894^{\mathrm{a}}$ & $0.875^{\mathrm{a}}$ & 0.885 \\
\hline Avoiding the risks of mal-adaptation to CC & $0.929^{a}$ & $0.838^{b}$ & 0.885 \\
\hline $\begin{array}{l}\text { Solving urban environmental problems } \\
\text { comprehensively }\end{array}$ & $0.918^{\mathrm{a}}$ & $0.800^{b}$ & 0.861 \\
\hline $\begin{array}{l}\text { Developing collective understanding } \\
\text { among related stakeholders }\end{array}$ & $0.894^{\mathrm{a}}$ & $0.813^{\mathrm{a}}$ & 0.855 \\
\hline $\begin{array}{l}\text { Increasing the efficiency of the urban } \\
\text { economy }\end{array}$ & $0.882^{\mathrm{a}}$ & $0.813^{\mathrm{a}}$ & 0.848 \\
\hline
\end{tabular}

The result highlights that an integrated approach between adaptation measures and urban development actions is an effective way not only to minimize the impacts and risks but also to achieve sustainable urban development. The earlier studies [37,48] highlighted that the integration strategy at the local level is able to ensure sustainability in the future. The finding confirms that both combination benefits are significant results because of the first and second-ranked drivers.

\section{Conclusions and Recommendations}

The integration of climate adaptation into urban development planning in the two coastal cities of Indonesia had been implemented at the early stage process with several on-going adaptation actions. It became essential to understand the progress of integration strategy based on stakeholders' perceptions related to the issues. This study perceived the results of the knowledge level of key actors, the influencing drivers, and the benefits from the integration approach. The findings were able to become the inputs to develop effective responses to improve the integrated strategy. However, the results were varied in both cities, depending on the context- and place-based strategy. Three significant conclusions have resulted from the study. First, the local experiences of key informants in both cities had a mixed result. Although, most of them understood the point of CC and its relationship with urban development. They perceived that $\mathrm{CC}$ and urban development are emerging issues and affecting environmental management. The findings revealed a significant result that it is essential to link climate adaptation into the urban development sector. However, there was a significant difference between the two different urbanized coastal areas. Even though it could not be generalized, larger urban coastal areas were more aware of the issues than smaller cities. Second, the findings highlighted the most drivers contributing to the integration in both cities, which are the motivation and initiative from local officers, capacity building, and the support by international agencies and central government. Third, there was a high consensus that integrating climate adaptation into urban development can ensure sustainable growth in the long-term and minimize CC impacts and risks. Most respondents understood that the integration would provide future sustainable development and reduce the effects. 
The findings confirm the assumption of this study that the engagement of local stakeholders in the integration process has increased their understanding of the issues of CC and urban development, for instance by looking at their perceptions of the benefits gained from the process. Their responses to the given statements on related issues result in similar highest scores in both cities. In addition, the respondents believe that the implementation of the integration strategy can ensure not only to reduce the CC impacts and risks but also to achieve sustainable urban development in the future.

This study recommends that understanding the local perspective is very important to assess. It aims to effectively develop the improvement of the efforts in the climate adaptation and urban development agenda. The issue of integration is multidimensional and shaped by non-climatic stressors and depending on the local context. This empirical research aimed to obtain a good lesson from the prior experiences of coastal cities that already conducted adaptation measures associated with urban development sectors. Their attainments could be applied to guide and encourage other local authorities in other areas.

Further studies should be carried out to get insights from other areas, including outside coastal cities within Indonesia. The integrated approach is vital to address the pressures of urban management and planning that will be increased by population growth, land-use change, and the effect of CC. This study recognizes the requirement for more specific and tailor-made support to allow municipal authorities to enhance their positive momentum and motivation toward integration strategy. The experiences from this study will able to share with other developing coastal cities.

Author Contributions: Conceptualization, N.W. and V.N.; methodology, N.W., R.P.S. and S.M.K.; formal analysis, N.W., V.N. and S.M.K.; investigation, N.W.; writing-original draft preparation, N.W.; writing-review and editing, N.W., V.N., R.P.S. and S.M.K.; visualization, N.W.; supervision, V.N., R.P.S. and S.M.K. All authors have read and agreed to the published version of the manuscript.

Funding: This research was funded by the Asian Institute of Technology Fellowship and the International Climate Initiative (11_II_077_ASIEN_A_Coastal Cities).

Acknowledgments: All the respondents who give up the time to be interviewed were gratefully acknowledged.

Conflicts of Interest: The authors declare no conflict of interest.

\section{References}

1. Hunt, A.; Watkiss, P. Climate change impacts and adaptation in cities: A review of the literature. Clim. Chang. 2011, 104, 13-49. [CrossRef]

2. $\quad$ Ranger, N.; Hallegatte, S.; Bhattacharya, S.; Bachu, M.; Priya, S.; Dhore, K.; Rafique, F.; Mathur, P.; Naville, N.; Henriet, F.; et al. An assessment of the potential impact of climate change on flood risk in Mumbai. Clim. Chang. 2011, 104, 139-167. [CrossRef]

3. UN-HABITAT. Cities and Climate Change Initiative. Launch and Conference Report; UN-HABITAT: Nairobi, Kenya, 2009.

4. UN-DESA. World Urbanization Prospects: The 2014 Revision; United Nations, Department of Economic and Social Affairs: New York, NY, USA, 2015.

5. IPCC. Climate Change 2014: Synthesis Report. In Contribution of Working Groups I, II and III to the Fifth Assessment Report of the Intergovernmental Panel on Climate Change; Pachauri, R.K., Meyer, L.A., Eds.; IPCC: Geneva, Switzerland, 2014.

6. Weiss, J. The Economics of Climate Change in Southeast Asia: A Regional Review; Asian Development Bank: Mandaluyong, Pilipinas, 2009; ISBN 9789715617871.

7. ICCSR. Indonesia Climate Change Sectoral Roadmap: Synthesis Report; BAPPENAS: Jakarta, Indonesia, 2009.

8. RAN-API. National Action Plan for Climate Change Adaptation (RAN-API): Synthesis Report; BAPPENAS: Jakarta, Indonesia, 2013.

9. Ayers, J.M.; Huq, S.; Faisal, A.M.; Hussain, S.T. Mainstreaming climate change adaptation into development: A case study of Bangladesh. Wiley Interdiscip. Rev. Clim. Chang. 2014, 5, 37-51. [CrossRef]

10. Fuchs, R.; Conran, M.; Louis, E. Climate Change and Asia's Coastal Urban Cities. Environ. Urban. ASIA 2011, 2, 13-28. [CrossRef] 
11. Measham, T.G.; Preston, B.L.; Smith, T.F.; Brooke, C.; Gorddard, R.; Withycombe, G.; Morrison, C. Adapting to climate change through local municipal planning: Barriers and challenges. Mitig. Adapt. Strateg. Glob. Chang. 2011, 16, 889-909. [CrossRef]

12. Rauken, T.; Mydske, K.; Winsvold, M. Mainstreaming climate change adaptation at the local level. Local Environ. 2015, 20, 408-423. [CrossRef]

13. Chu, E.K. Urban climate adaptation and the reshaping of state-society relations: The politics of community knowledge and mobilisation in Indore, India. Urban. Stud. 2018, 55, 1766-1782. [CrossRef]

14. Leichenko, R. Climate change and urban resilience. Curr. Opin. Environ. Sustain. 2011, 3, 164-168. [CrossRef]

15. Bulkeley, H. Cities and the Governing of Climate Change. Annu. Rev. Environ. Resour. 2010, 35, $229-253$. [CrossRef]

16. Bulkeley, H. Cities and Climate Change, 1st ed.; Routledge: Abingdon, UK, 2013; ISBN 9780203077207.

17. Klein, R.J.T.; Smith, J.B. Enhancing the Capacity of Developing Countries to Adapt to Climate Change: A Policy Relevant Research Agenda. In Climate Change, Adaptive Capacity and Development; Imperial College Press: London, UK, 2003; pp. 317-334.

18. Huq, S.; Reid, H.; Konate, M.; Rahman, A.; Sokona, Y.; Crick, F. Mainstreaming adaptation to climate change in Least Developed Countries (LDCs). Clim. Policy 2004, 4, 25-43. [CrossRef]

19. Agrawala, S.; Van Aalst, M. Bridging the Gap Between Climate Change and Development. In Bridge Over Troubled Waters: Linking Climate Change and Development; OECD Publishing: Paris, France, 2005; pp. 133-146. ISBN 9789264012752.

20. Birkmann, J.; Garschagen, M.; Kraas, F.; Quang, N. Adaptive urban governance: New challenges for the second generation of urban adaptation strategies to climate change. Sustain. Sci. 2010, 5, 185-206. [CrossRef]

21. Ignatowski, J.A.; Rosales, J. Identifying the exposure of two subsistence villages in Alaska to climate change using traditional ecological knowledge. Clim. Chang. 2013, 121, 285-299. [CrossRef]

22. Mercer, J.; Kelman, I.; Taranis, L.; Suchet-Pearson, S. Framework for integrating indigenous and scientific knowledge for disaster risk reduction. Disasters 2010, 34, 214-239. [CrossRef] [PubMed]

23. Adger, W.N.; Dessai, S.; Goulden, M.; Hulme, M.; Lorenzoni, I.; Nelson, D.R.; Naess, L.O.; Wolf, J.; Wreford, A. Are there social limits to adaptation to climate change? Clim. Chang. 2009, 93, 335-354. [CrossRef]

24. Harvatt, J.; Petts, J.; Chilvers, J. Understanding householder responses to natural hazards: Flooding and sea-level rise comparisons. J. Risk Res. 2011, 14, 63-83. [CrossRef]

25. Smit, B.; Burton, I.; Klein, R.J.T.; Wandel, J. An Anatomy of Adaptation to Climate Change and Variability. In Societal Adaptation to Climate Variability and Change; Springer: Dordrecht, The Netherlands, 2000; pp. 223-251.

26. IPCC. Climate Change 2007: Synthesis Report; An Assessment of the Intergovernmental Panel on Climate Change; Pachauri, R.K., Reisinger, A., Eds.; IPCC: Geneva, Switzerland, 2007.

27. Agrawal, A. Climate adaptation, local institutions, and rural livelihoods. In Adapting to Climate Change: Thresholds, Values, Governance; Adger, W.N., Lorenzoni, I., O’Brien, K.L., Eds.; Cambridge University Press: Cambridge, UK, 2009.

28. Cullis, J.; Strzepek, K.; Tadross, M.; Sami, K.; Havenga, B.; Gildenhuys, B.; Smith, J. Incorporating climate change into water resources planning for the town of Polokwane, South Africa. Clim. Chang. 2011, 108, 437-456. [CrossRef]

29. Feldmeyer, D.; Wilden, D.; Kind, C.; Kaiser, T.; Goldschmidt, R.; Diller, C.; Birkmann, J. Indicators for Monitoring Urban Climate Change Resilience and Adaptation. Sustainability 2019, 11, 2931. [CrossRef]

30. Laukkonen, J.; Blanco, P.K.; Lenhart, J.; Keiner, M.; Cavric, B.; Kinuthia-Njenga, C. Combining climate change adaptation and mitigation measures at the local level. Habitat Int. 2009, 33, 287-292. [CrossRef]

31. Pasquini, L.; Cowling, R.M.; Ziervogel, G. Facing the heat: Barriers to mainstreaming climate change adaptation in local government in the Western Cape Province, South Africa. Habitat Int. 2013, 40, $225-232$. [CrossRef]

32. Sarzynski, A. Public participation, civic capacity, and climate change adaptation in cities. Urban. Clim. 2015, 14, 52-67. [CrossRef]

33. Hjerpe, M.; Glaas, E. Evolving local climate adaptation strategies: Incorporating influences of socio-economic stress. Mitig. Adapt. Strateg. Glob. Chang. 2012, 17, 471-486. [CrossRef]

34. Araos, M.; Berrang-Ford, L.; Ford, J.D.; Austin, S.E.; Biesbroek, R.; Lesnikowski, A. Climate change adaptation planning in large cities: A systematic global assessment. Environ. Sci. Policy 2016, 66, 375-382. [CrossRef] 
35. OECD. Integrating Climate Change Adaptation into Development Co-operation: Policy Guidance; OECD Publishing: Paris, France, 2009; ISBN 978-92-64-05476-9.

36. Oliver-Smith, A. Sea Level Rise and the Vulnerability of Coastal Peoples: Responding to the Local Challenges of Global Climate Change in the 21st Century; UNU-EHS: Bonn, Germany, 2009; ISBN 9783939923282.

37. Persson, Å.; Klein, R.J.T. Mainstreaming adaptation to climate change in official development assistance: Challenges to foreign policy integration. In Climate Change and Foreign Policy: Case Studies from East to West; Harris, P., Ed.; Routledge: London, UK, 2009; pp. 162-177. ISBN 9780415483452.

38. Sherman, M.; Berrang-Ford, L.; Lwasa, S.; Ford, J.; Namanya, D.B.; Llanos-Cuentas, A.; Maillet, M.; Harper, S. IHACC Research Team Drawing the line between adaptation and development: A systematic literature review of planned adaptation in developing countries. Wiley Interdiscip. Rev. Clim. Chang. 2016, 7, 707-726. [CrossRef]

39. Birkmann, J.; Garschagen, M.; Setiadi, N. New challenges for adaptive urban governance in highly dynamic environments: Revisiting planning systems and tools for adaptive and strategic planning. Urban. Clim. 2014, 7, 115-133. [CrossRef]

40. Paudel, N.S.; Khatri, D.B.; Ojha, H.; Karki, R.; Gurung, N.; Dhungana, H.; Shrestha, K.K.; Bir Bajracharya, S. Integrating Climate Change Adaptation with Local Development: Exploring Institutional Options. J. For. Livelihood 2013, 11, 1-13. [CrossRef]

41. Picketts, I.M.; Déry, S.J.; Curry, J.A. Incorporating climate change adaptation into local plans. J. Environ. Plan. Manag. 2014, 57, 984-1002. [CrossRef]

42. Wijaya, N.; Bisri, M.B.F.; Aritenang, A.F.; Mariany, A. Spatial Planning, Disaster Risk Reduction, and Climate Change Adaptation Integration in Indonesia: Progress, Challenges, and Approach. In Disaster Risk Reduction in Indonesia. Disaster Risk Reduction (Methods, Approaches and Practices); Djalante, R., Garschagen, M., Thomalla, F., Shaw, R., Eds.; Springer: Berlin/Heidelberg, Germany, 2017; pp. 235-252. ISBN 978-3-319-54466-3.

43. ACCCRN Indonesia Program Team. Climate Change Adaptation Towards Urban. Resilience; Mercy, C., Ed.; Mercy Corps Indonesia: Jakarta, Indonesia, 2018.

44. Baker, I.; Peterson, A.; Brown, G.; McAlpine, C. Local government response to the impacts of climate change: An evaluation of local climate adaptation plans. Landsc. Urban. Plan. 2012, 107, 127-136. [CrossRef]

45. Dannevig, H.; Hovelsrud, G.K.; Husabø, I.A. Driving the Agenda for Climate Change Adaptation in Norwegian Municipalities. Environ. Plan. C Gov. Policy 2013, 31, 490-505. [CrossRef]

46. Pilato, G.; Sallu, S.; Gaworek-Michalczenia, M. Assessing the Integration of Climate Change and Development Strategies at Local Levels: Insights from Muheza District, Tanzania. Sustainability 2018, 10, 174. [CrossRef]

47. UNDP-UNEP. Mainstreaming Climate Change Adaptation into Development Planning: A Guide for Practitioners; UNDP-UNEP Poverty-Environment Facility: Nairobi, Kenya, 2011.

48. Lebel, L.; Li, L.; Krittasudthacheewa, C.; Juntopas, M.; Vijitpan, T.; Uchiyama, T.; Krawanchid, D. Mainstreaming Climate Change Adaptation into Development Planning; Adaptation Knowledge Platform and Stockholm Environment Institute: Bangkok, Thailand, 2012.

49. ACCCRN. City Resilience Strategy: Semarang's Adaptation Plan in Responding to Climate Change; ACCCRN: Semarang, Indonesia, 2010.

50. ACCCRN. Vulnerability and Adaptation Assessment to Climate Change in Bandar Lampung City; ACCCRN: Bandar Lampung, Indonesia, 2010.

51. CSA. Semarang Municipality in Figure 2018; Central Statistical Agency of Semarang: Semarang, Indonesia, 2018.

52. CSA. Bandar Lampung Municipality in Figure 2018; Central Statistical Agency of Bandar Lampung: Bandar Lampung, Indonesia, 2018.

53. Tyler, S.; Nugraha, E.; Kim Nguyen, H.; Van Nguyen, N.; Delima Sari, A.; Thinpanga, P.; Thanh Tran, T.; Shanker Verma, S. Indicators of urban climate resilience: A contextual approach. Environ. Sci. Policy 2016, 66, 420-426. [CrossRef]

54. Revi, A.; Satterthwaite, D.; Aragón-Durand, F.; Corfee-Morlot, J.; Kiunsi, R.B.R.; Pelling, M.; Roberts, D.; Solecki, W.; Gajjar, S.P.; Sverdlik, A. Towards transformative adaptation in cities: The IPCC's Fifth Assessment. Environ. Urban. 2014, 26, 11-28. [CrossRef]

55. Nanna, M.J.; Sawilowsky, S.S. Analysis of Likert scale data in disability and medical rehabilitation research. Psychol. Methods 1998, 3, 55-67. [CrossRef]

56. Wijaya, N. Climate change adaption measures in the coastal city of Semarang, Indonesia: Current practices and performance. J. Reg. City Plan. 2015, 26, 28-42. [CrossRef] 
57. Grothmann, T.; Patt, A. Adaptive capacity and human cognition: The process of individual adaptation to climate change. Glob. Environ. Chang. 2005, 15, 199-213. [CrossRef]

58. Hulme, M. Problems with making and governing global kinds of knowledge. Glob. Environ. Chang. 2010, 20, 558-564. [CrossRef]

(C) 2020 by the authors. Licensee MDPI, Basel, Switzerland. This article is an open access article distributed under the terms and conditions of the Creative Commons Attribution (CC BY) license (http://creativecommons.org/licenses/by/4.0/). 